
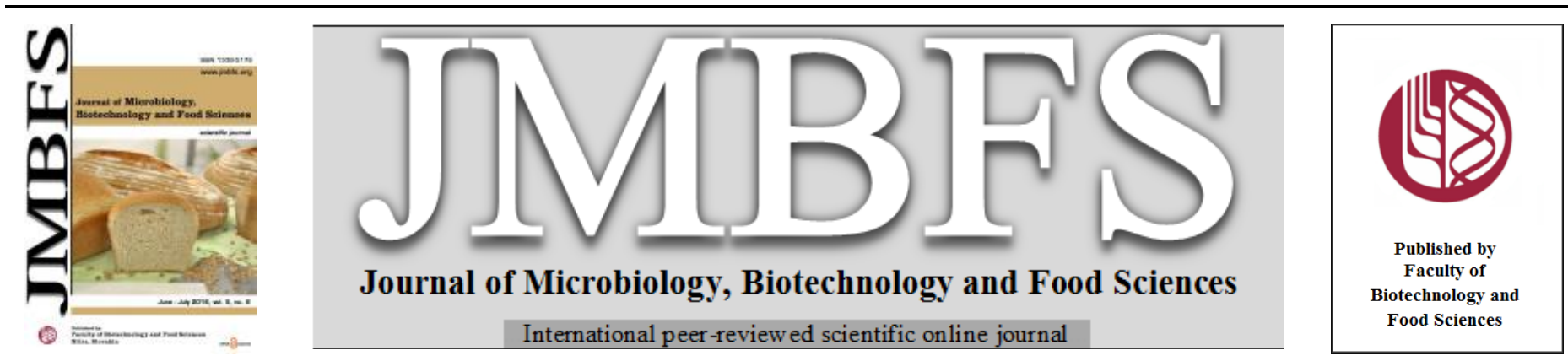

\title{
EFFECT OF COMMERCIALLY MANUFACTURED KAPPA SEMI-REFINED CARRAGEENAN (SRC) WITH DIFFERENT PHOSPHATE SALTS ON YIELD, TEXTURAL AND SENSORY PROPERTIES OF BEEF MEAT
}

\author{
Marimuthu Murugesan, Ilansuriyan Packrisamy, Tony N Yap, Shanmugam Munisamy* \\ Address(es): Dr. Shanmugam Munisamy, \\ Food Ingredients Group, Research and Development Division, AquAgri Processing Private Limited, B5, SIPCOT Industrial Complex, Manamadurai - 630 606, \\ Sivaganga District, Tamil Nadu, INDIA.
}

*Corresponding author: m.shanmugam@aquagri.in

doi: $10.15414 / j m b f s .2016 .5 .6 .518-522$

\section{ARTICLE INFO}

Received 16. 11. 2015

Revised 7. 12. 2015

Accepted 14. 1. 2016

Published 1. 6. 2016

Regular article

open $\partial_{\text {ACCESS }}$

\section{ABSTRACT}

The phosphate salts such as SDP, TSP, SHMP, DSP, TPPP, TKPP and STPP were blended with semi-refined kappa carrageenan (SRC) individually and their aqueous solution was injected into the fresh beef meat. The highest weight gain (24\%) in fresh meat was obtained from injection of blend made with SRC and STPP as compared to other blends and control sample after forzen storage. Similarly, it also showed low cooking loss $(24 \%)$ with good testural and sensory proerties as compared to other blends. It can be concluded from the presnt study that blend of SRC and STPP can be used in beef meat for yield and quality improvement.

Keywords: Beef, Semi Refined Carrageenan, Phosphate salts, Sensory analysis, Texture

\section{INTRODUCTION}

Nowadays, trendy sophisticated lifestyle makes the people moving towards modern technology especially in food processing side. They are looking for the solutions which fulfil their day by day needs. As we know, perishable products like meat and dairy usage among people requires specific concentration. For this sake it has technology like infusion of hydrocolloids and salts to make the product such as beef, poultry, pork and fish with better flavour texture, tenderness and juiciness for the customer satisfaction. Generally salts having good functional properties using in meat and meat products, which acts as preservative, binding to water and fat, textural properties and increasing shelf life by controlling water activity (Bess, 2011). Cooking loss, texture deterioration, decrease shelf life are the important factors affected by the reduction of salt in meat products, and at the same time there were controversy in hypertension, so there was mandatory to control the salt limits in meat and meat products. Sodium phosphate is generally used to increase moisture retention and reduce oxidative rancidity in meat (Baumert and Mandigo, 2005). Today, the meat industry offers a variety of different formulations to meet different nutrition needs.

Wierbicki and Howker (1976) observed that phosphates and $\mathrm{NaCl}$ at different levels showed various effects on colour, quality and sensory characteristics of beef and found that at 3\% salt, either $0.3 \%$ STPP or $0.217 \%$ TSPP with other curing ingredients was an acceptable limit for cut-and-formed smoked as well as cured ham (Wierbicki and Howker, 1976). Baublits et al. (2005) studied the effect of the addition of STPP, SHMP and TSPP at the concentration 0.2 and $0.4 \%$ along with $2 \% \mathrm{NaCl}$ on color, quality, and sensory characteristics of beef and observed that STPP was the most effective phosphate type for improving the color at the concentration $0.4 \%$ at the injection rate $18 \%$ (Baublits et al., 2005). Torley et al. (2000) had observed that TSPP $(0.35 \%)$ and STPP $(0.37 \%)$ on pale soft exudative (PSE) pork had small effects on the functional properties such as $\mathrm{pH}$, cooking temperature and ionic strength than in normal pork meat and concluded that addition of polyphosphates only gave a lower cooking loss through texture.

Tetra sodium diphsphates are the most functional phosphates in meat products. They act on the actomyosin complex of meat protein and also have high $\mathrm{pH}$ value. It results in high protein solubility which induces good water binding capacity (Molins, 1991; Zayas, 1997). Short chain phosphates are used as improving emulsion water holding capacity and stability (Feiner, 2006; Zayas, 1997) whereas the long chain phosphates such as SHMP and STTP used for optimize solubility and functionality of meat products (Alvarado and McKee, 2007; Anjaneyulu et al., 1989; Offer and Trinick, 1983). The addition of $\mathrm{NaC}$ or STPP and a lower pH led to an increase in the metmyoglobin level
(Fernández-López et al., 2004; Moiseev and Cornforth, 1997) in meat. Anjaneyulu et al. (1990) had reported that application of phosphate blends on buffalo meat patties improved the level of emulsifying capacity, increased emulsion stability, yield of patties, water holding capacity and reduced cooking loss, then shrinkage of patties. The phosphates such as TSPP, STPP and SAPP with $\mathrm{NaCl}$ in various concentrations had played a main role on buffalo meat and that the effects of phosphate were always comparatively better than sodium blends and control (Anjaneyulu et al., 1990). Phosphates with kappacarrageenan salt on the low fat emulsified meatballs significantly affect the product cooking yield, adhesion, gumminess, chewiness, lipid content, hardness, viscosity, cohesiveness and brittleness. The combination of salt and polyphosphates had effects on the product's texture and overall acceptance (Hsu and Chung, 2001).

Carrageenans are highly flexible molecules that form helical structure which has ability to form a variety of different gels at room temperature. Red sea weeds are the sources of carrageenan i.e., linear anionic sulphated polymer of galactose and anhydrogalactose. They are used in the food industries such as canned meat, reduced fat products for its gelling characteristic, water binding properties and thickening (Giese, 1992; Therkelsen et al., 1993; Candogan and Kolsarici, 2003a,b; Bixler and Porse, 2011). The function of carrageenan in meat and its adding to the low-fat meat products improves water retention, consistency, slicebility and texture. DeFreitas et al. (1997) evaluated the effects of $\kappa_{-}^{-}, \imath^{-}$, and $\lambda$-carrageenan (CGNs) on the rheological properties, water loss, and ultra structure of salt-soluble meat protein (SSMP) gels and found that $\kappa$-CGN increased gel strength and water retention of SSMP. At 0.2 to $1.5 \%$ of carrageenan in turkey meat sausage caused reduction of emulsion stability and increased water holding capacity (Ayadi et al., 2009) also addition of carrageenan to increase emulsion stability in low fat frankfurter was reported by Candogan and Kolsarici (2003a). Influence of carrageenan on sensory properties of sausages showed that it could improve sensory scores in beef sausages (Xiong et al., 1999).

The present study was to evaluate the effect of blends prepared with commercially manufactured semi refined carrageenan (MK-250 is brand name of AquAgri for food application) and different phosphates on yield, textural and sensory properties of beef meat with different phosphate salts. 


\section{MATERIAL AND METHODS}

\section{Sample collection}

Beef biceps femoris (breeds: Jersey; sex: male, age: 2 years) was purchased from local meat shop and it was kept in refrigerator $\left(4^{\circ} \mathrm{C}\right)$ for about 2 hours till it was used for the experiment, then ligaments, tendons and extraneous tissues were removed as much as possible and cut into $100 \mathrm{~g}$ pieces with almost similar shape using a meat cutter.

\section{SRC \& Phosphate Salts}

Semi-refined carrageenan (MK-250 is a brand name of AquAgri for food application) with particle mesh size of 200 mesh $(0.074 \mathrm{~mm})$ used was from stock of Aquagri Processing Private Limited Batch No-108/2015, Manamadurai, India The salts of Sodium Phosphate dibasic (SDP), trisodium orthophosphate (TSP), Sodium hexa meta phosphate (SHMP), Sodium dihydrogen orthophosphate dehydrate (DSP), Tetra potassium pyrophosphate (TPPP), Di sodium hydrogen orthophosphate anhydrous (TKPP), Sodium tripolyphosphate (STPP) were purchased from LOBA Chemicals Private Limited, Mumbai, India. Water bath 250 W, Sigma Scientific Instrument (P) Ltd, Chennai, India, Blue Star Chest freezer, Model CHF 200 B, India, Sony Cyber shot, GPS- DSC- HX 200 were used in the present investigation.

\section{Preparation of Brine solution}

Brine solutions were freshly prepared and used. Seven phosphate salts viz. SDP TSP, SHMP, DSP, TPPP, TKPP and STPP were mixed separately with semirefined carrageenan $(\mathrm{MK}-250)$ at 1:3 ratio in chilled water $\left(5^{\circ} \mathrm{C}\right)$ and used.

\section{Meat treatment}

All Part of biceps femoris was usedpieces was injected with $30 \%$ of its initial weight with freshly prepared brine solution by using syringe and the meat piece without brine injection was treated as control sample. Both treated and contro samples were stored in freezer at $-18^{\circ} \mathrm{C}$ for two days. Then samples were taken out, allowed to thaw and weight gain was calculated after drip loss. The samples were subjected to cooking at optimum temperature level of $80^{\circ} \pm 2^{\circ} \mathrm{C}$. Each sample was tagged with the wooden card board with nylon thread for identity. The experiment was replicated and average of data obtained from two experiments was considered.

\section{Analysis of Physicochemical parameters}

$\mathrm{pH}$ of sample was measured by using an electrical automatic $\mathrm{pH}$ meter (Eutech Instruments, Malaysia). A few drops of distilled water was sprayed on meat and measured the $\mathrm{pH}$ by direct contact between the sensitive diaphragm of the electrode and meat tissue.

Moisture of meat samples was determined according to AOAC method (AOAC 1990). Meat sample was weighed in pre-weighed crucibles and charred on a hot plate and then placed in a muffle furnace at $550^{\circ} \mathrm{C}$ for 4 hours and total ash was measured as below:

Ash Content $(\%)=$ weight of residue after ashing $(\mathrm{g}) /$ Weight of sample $(\mathrm{g}) * 100$

\section{Yield calculation}

The cooked yield was calculated in relation to the raw meat weight (before injection) (Drummond and Da-Wen Sun, 2006) using the following equation: Cooked yield $(\%)=$ Cooked weight $/$ Raw weight $* 100$

\section{Textural analysis}

Extract release volume (ERV) of meat was determined using the method described by Jay (1964). 20g of meat was homogenised with $100 \mathrm{ml}$ of distilled water for 2 minutes. Then poured the homogenate directly into the funnel lined with Whatman filter paper No.1, folded thrice as to make eight sections and allowed the homogenate to seep between the folds. The volume collected in 15 min was considered for calculating ERV.

Meat swelling capacity (MSC) of meat was determined by method of Leora et al. (2006). $25 \mathrm{~g}$ of meat was homogenised with $100 \mathrm{ml}$ distilled water for 2 minutes. Then $35 \mathrm{ml}$ of homogenate was centrifuged at $2000 \mathrm{rpm}$ for 15 minute and collected the supernatant (S) and calculated the MSC as below.

\section{$\%$ Meat Swelling Capacity $=(35-\mathrm{S}-7) / 7 * 100$}

Water holding capacity (WHC) of meat was measured using the method described by Kauffman et al. (1986) and Trout (1998). $0.5 \mathrm{~g}$ of meat sample was weighed and placed in between filter papers and this in turn was placed between glass sheets weighing $1.58 \mathrm{~kg}$. Over it, a weight of $4.0 \mathrm{~kg}$ weight was place, thus total weight including glass sheet was $5.58 \mathrm{~kg}$ for $5 \mathrm{~min}$. The water from the meat was then absorbed on the filter paper and filter paper was dried. Then area of the filter paper marked with and meat was later determined using a compensatory planimeter. Taking the differences from the resulting areas of the sample from marked borderline on the filter paper (moisture) and meat and a ratio area marked borderline was expressed as water holding capacity (WHC) of the meat:

WHC $\%=($ Area marked borderline - Area meat $) * 100 /$ Area marked borderline

\section{Sensory analysis}

Ten panellists were chosen for the assessment of the sensory attributes of the cooked beef meat samples. The samples were coded with alphabets and served to the panellists in individually partitioned booths. Sensory property was evaluated using standard evaluation score card ( 9 hedonic scales). Statistical analysis was done according to method described by Steel et al. (1996).

\section{RESULTS AND DISCUSSION}

The weight extension in brine injected meat samples ranged between 16 to $24 \%$. The highest weight gain was observed in brine prepared with STPP and injected in meat i.e. $24 \%$ and it was $21 \%, 20 \%, 19 \%, 17 \%$, and $16 \%$ in TPPP, SHMP TSP, SDP \& TKPP and DSP blended with MK-250 and injected in meat samples respectively, thus the response of different phosphates in weight extension of beef meat follows as: TPPP $>$ TPPP $>$ SHMP $>$ TSP $>$ SDP \& TKPP $>$ DSP. In the control sample there was $4 \%$ weight loss was recorded. Similarly lowest cooking loss i.e. $34 \%$ observed with beef sample treated with STPP followed by TPPP (26\%), TSP (28\%), SHMP (30\%), SDP \& TKPP (34\%) and DSP (35\%) (Table 1). Garcia et al. (2013) and Lee et al. (2014) had reported that addition of kappa carrageenan improved the yield and textural characteristics of beef and similar effect was observed in pork by Patrascu et al. (2013). Blend of STPP also showed lowest cooking loss of $38.70 \%$ followed by TSP $(39.49 \%)$ and in other phosphates, the cooking loss ranged between in $40.49 \%$ to $43.58 \%$.and in control it was $47.91 \%$. The net weight loss from raw meat to after cooking ranged from $24 \%$ to $35 \%$ in treated samples with STPP being lowest weight loss (24\%) and in control meat sample the weight loss was $50 \%$ (Table 1). It has been reported in literature that decreasing cooking loss was observed when treating muscle with a brine solution (Sheard et al., 1999; Walsh et al., 2010).

Table 1 Yield improvement and cooking loss of beef meat injected with blend of SRC (MK- 250) and different phosphates *

\begin{tabular}{|c|c|c|c|c|c|c|}
\hline Blend & $\begin{array}{c}\text { Initial } \\
\text { weight(g) }\end{array}$ & $\begin{array}{l}\text { Weight } \\
\text { after } \\
\text { injection } \\
(\mathrm{g})\end{array}$ & $\begin{array}{l}\text { Weight after } \\
\text { storage (after } \\
\text { drip loss) (g) }\end{array}$ & $\begin{array}{l}\text { Weight post } \\
\text { cooking }(\mathrm{g})\end{array}$ & $\begin{array}{c}\text { Weight after } \\
\text { cooking loss }(\%)\end{array}$ & $\begin{array}{c}\text { Net loss for } \\
\text { initial weight of } \\
100 \mathrm{~g}(\%)\end{array}$ \\
\hline $\mathrm{MK}-250+\mathrm{SDP}$ & 100 & 130 & 117 & 66 & 43.58 & 34 \\
\hline $\mathrm{MK}-250+\mathrm{TSP}$ & 100 & 130 & 119 & 72 & 39.49 & 28 \\
\hline MK-250 +SHMP & 100 & 130 & 120 & 70 & 41.66 & 30 \\
\hline MK-250 + DSP & 100 & 130 & 116 & 65 & 43.96 & 35 \\
\hline MK-250 + TPPP & 100 & 130 & 121 & 72 & 40.49 & 28 \\
\hline MK-250 + TKPP & 100 & 130 & 117 & 66 & 43.58 & 34 \\
\hline MK-250 + STPP & 100 & 130 & 124 & 76 & 38.70 & 24 \\
\hline Control & 100 & 100 & 96 & 50 & 47.91 & 50 \\
\hline
\end{tabular}

The $\mathrm{pH}$ of brine made with different phosphates ranged from 6.53 to 11.67 with the order of TSP (11.67) > TKPP (10.75) > SDP (10.20), STPP (10.17), TPPP (10.09), SHMP (7.75 and slight acidic pH in DSP (6.53). The $\mathrm{pH}$ of raw meat was 5.54 and phosphate salts ranged from slight acidic (DSP $\mathrm{pH}$ 6.53) to high alkali condition of TSP ( $\mathrm{pH} 11.67)$. The $\mathrm{pH}$ of brine injected meat and cooked increased from $\mathrm{pH}$ of its raw meat samples but all within acidic condition (Table 2) including TSP injected meat. The $\mathrm{pH}$ of meat improves little after injection of phosphate salts, thereby structure of muscle protein is opened as to increase the water holding capacity in order to yield extended weight gain and decreasing cooking losses (Knipe, 2003 and Molins, 1991). It has also been reported by Xiong et al. (1999) that an increase in $\mathrm{pH}$ sharply enhanced the water binding 
strength in beef sausage when injected with some gums including carrageenans along with salts.

Table 2 Physiochemical properties beef meat injected with blend of SRC (MK- 250) and different phosphates*

\begin{tabular}{|c|c|c|c|c|c|c|c|c|c|c|c|}
\hline \multirow[b]{2}{*}{$\begin{array}{l}\text { Meat } \\
\text { Blends }\end{array}$} & \multicolumn{3}{|c|}{ Moisture } & \multicolumn{3}{|c|}{ Ash } & \multicolumn{5}{|c|}{$\mathrm{pH}$} \\
\hline & $\begin{array}{l}\text { Raw } \\
\text { Meat }\end{array}$ & $\begin{array}{l}\text { Injecte } \\
\text { d Meat }\end{array}$ & $\begin{array}{c}\text { Cooked } \\
\text { Meat }\end{array}$ & $\begin{array}{c}\text { Raw } \\
\text { Mea } \\
t\end{array}$ & $\begin{array}{c}\text { Injected } \\
\text { Meat }\end{array}$ & $\begin{array}{c}\text { Cooked } \\
\text { Meat }\end{array}$ & $\begin{array}{l}\text { Raw } \\
\text { meat }\end{array}$ & Salts & $\begin{array}{c}\text { Salts } \\
\text { with } \\
\text { MK-250 }\end{array}$ & $\begin{array}{c}\text { Injected } \\
\text { Meat }\end{array}$ & $\begin{array}{c}\text { Cooke } \\
\text { d } \\
\text { Meat }\end{array}$ \\
\hline MK-250 + SDP & 56.80 & 64.07 & 63.92 & 0.58 & 0.63 & 0.98 & 5.54 & 8.98 & 10.20 & 6.17 & 6.55 \\
\hline $\mathrm{MK}-250+\mathrm{TSP}$ & 56.78 & 69.34 & 67.09 & 0.58 & 0.68 & 0.97 & 5.54 & 11.86 & 11.67 & 6.48 & 6.78 \\
\hline MK-250 +SHMP & 56.12 & 66.21 & 67.12 & 0.58 & 0.65 & 0.96 & 5.54 & 5.43 & 7.75 & 6.01 & 6.44 \\
\hline $\mathrm{MK}-250+\mathrm{DSP}$ & 56.74 & 60.69 & 64.72 & 0.57 & 0.74 & 0.98 & 5.54 & 4.41 & 6.53 & 5.75 & 6.25 \\
\hline MK-250 + TPPP & 56.86 & 60.46 & 63.09 & 0.58 & 0.62 & 0.97 & 5.54 & 10.01 & 10.09 & 6.04 & 6.42 \\
\hline MK-250 + TKPP & 56.22 & 60.76 & 64.78 & 0.57 & 0.63 & 0.97 & 5.54 & 8.93 & 10.75 & 6.24 & 6.74 \\
\hline MK-250 + STPP & 56.54 & 60.81 & 65.18 & 0.58 & 0.61 & 0.98 & 5.54 & 8.94 & 10.17 & 6.06 & 6.45 \\
\hline Control & 56.80 & 56.80 & 60.02 & 0.58 & 0.58 & 0.97 & 5.54 & - & - & 5.56 & 6.04 \\
\hline
\end{tabular}

*Each value is a mean of duplicates

\section{Moisture and Ash content}

The ash and moisture content of meat injected with brine and its respective control is given in Table 2. Moisture of raw meat ranged between 56.12 to $56.86 \%$ and ash content was 0.57 to $0.58 \%$. Because of specificity of the blend created with SRC (MK-250), the injected meat and cooked meat had shown increasing the moisture and ash level when compare to the raw meat due to its higher water holding capacity. The moisture level in control sample was $56.80 \%$ and $60.02 \%$ and ash content was $0.58 \%$ and $0.97 \%$ in raw and cooked meat respectively. In the treated meat, TSP had highest moisture content of $69.34 \%$ and lowest moisture level was observed in meat injected with TPPP (60.46\%). The range of ash content in treated meat was very short i.e. $0.61 \%$ to $0.74 \%$ with lowest level in STPP and highest in DSP treated meat. Similarly, in the case of respective cooked meat, SHMP treated meat showed highest moisture level of $67.12 \%$ and lowest moisture was observed with meat treated by TPPP i.e. $63.09 \%$. The ash content of all the samples treated with different phosphate salts and control was within the range from 0.97 to $0.98 \%$.

\section{Textural properties}

The textural properties of raw, injected and cooked beef meat are presented in Table 3 and Figure1-2. The average ERV values of raw beef were $54 \mathrm{ml}$, while water holding capacity was $28.34 \%$ and meat swelling capacity was $40 \%$. For injected beef meat, highest ERV value was observed with STPP treated meat i.e. $53 \%$ followed by TKPP (52\%), control $(52 \%)$, TPPP (51\%), TSP (50\%), DSP (49\%), SDP (48\%) and SHMP (48\%) treated meat samples (Table 3 and Figure 3 ). Water holding capacity of the beef meat refers to its ability of retain water and it is affected by space in muscle and $\mathrm{pH}$ of the tissue. The WHC of injected meat ranged from $26.12 \%$ to $44.89 \%$ with the order of STPP $(44.89 \%)>$ TPPP $(43.52 \%)>\operatorname{SHMP}(43.22 \%)$ and the lowest range as TSP $(42.16 \%)>\operatorname{SDP}$ $(41.94 \%)>\operatorname{TKPP}(40.71 \%)>\operatorname{DSP}(40.50 \%)$ and control $(26.12 \%)$ (Figure 4$)$ Verbeken (2003) reported that increasing the concentration of carrageenan from 0 to $2 \%$ led to an increase in WHC of about $5 \%$ and most studies reported a better water retention in the presence of carrageenan (Pietrasik and Duda, 2000; Pietrasik and Li-Chan, 2002; Pietrasik, 2003). it was 52\%, 51\%, 50\%, 49\%, and $48 \%$ in

Table 3 Textural properties beef meat injected with blend of semi-refined carrageenan (MK- 250) and different phosphates*

\begin{tabular}{lccccccccc}
\hline & \multicolumn{3}{c}{ Raw meat } & \multicolumn{3}{c}{ Injected meat } & \multicolumn{3}{c}{ Cooked Meat } \\
\cline { 2 - 10 } Meat Blends & $\begin{array}{c}\text { ERV } \\
(\mathrm{ml})\end{array}$ & $\begin{array}{c}\text { WHC } \\
(\%)\end{array}$ & $\begin{array}{c}\text { MSC } \\
(\%)\end{array}$ & $\begin{array}{c}\text { ERV } \\
(\mathrm{ml})\end{array}$ & $\begin{array}{c}\text { WHC } \\
(\%)\end{array}$ & $\begin{array}{c}\text { MSC } \\
(\%)\end{array}$ & $\begin{array}{c}\text { ERV } \\
(\mathrm{ml})\end{array}$ & $\begin{array}{c}\text { WHC } \\
(\%)\end{array}$ & $\begin{array}{c}\text { MSC } \\
(\%)\end{array}$ \\
\hline MK-250 + SDP & 54 & 28.34 & 40 & 48 & 41.94 & 45.71 & 20 & 38.94 & 20.00 \\
MK-250 + TSP & 54 & 28.34 & 40 & 50 & 42.16 & 42.85 & 18 & 39.16 & 17.14 \\
MK-250 +SHMP & 54 & 28.34 & 40 & 48 & 43.22 & 45.71 & 17.5 & 40.12 & 22.85 \\
MK-250 + DSP & 54 & 28.34 & 40 & 49 & 40.50 & 48.57 & 18 & 37.50 & 14.28 \\
MK-250 + TPPP & 54 & 28.34 & 40 & 51 & 43.52 & 51.42 & 21 & 39.25 & 17.14 \\
MK-250 + TKPP & 54 & 28.34 & 40 & 52 & 40.71 & 48.57 & 18.5 & 37.71 & 18.57 \\
MK-250 + STPP & 54 & 28.34 & 40 & 53 & 44.89 & 42.85 & 20 & 40.82 & 28.57 \\
Control & 54 & 28.34 & 40 & 52 & 26.12 & 34.28 & 36.5 & 24.46 & 11.42 \\
\hline *Each value is a mean of duplicates & & & & & & & &
\end{tabular}

*Each value is a mean of duplicates

The MSC of injected beef meat as follows from highest to lowest TPPP $(51.42 \%)$, DSP and TKPP (48.57\%), SDP and SHMP (45.71), STPP and TSP $(42.85 \%)$ and control $(34.28 \%)$ (Figure 5$)$. The cooked beef meat had lowest ERV value (18\%) was found using DSP and TSP added with MK-250 while the highest ERV value is found in control $36.5 \%$. The highest WHC obtained for cooked meat using STPP with MK-250 (40.82\%) and while the lowest WHC is for control (24.46). STPP had highest MSC value is $28.57 \%$ for STPP with MK250 and lowest MSC is $11.42 \%$ for control. The TSP and TPPP has similar MSC value $(17.14 \%)$
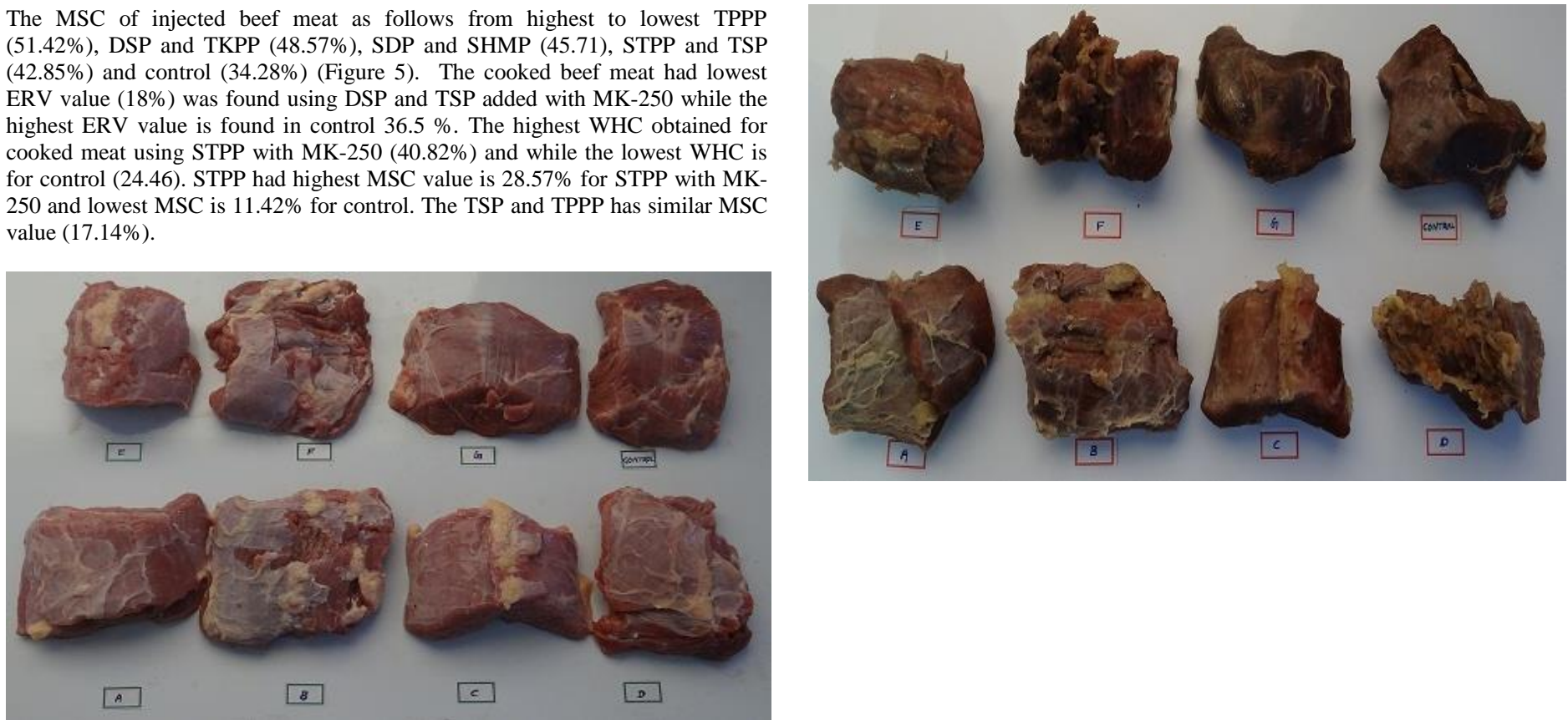

Figure 1 Texture of beef meat injected with blend of semi-refined carrageenan (MK- 250) and different phosphates 


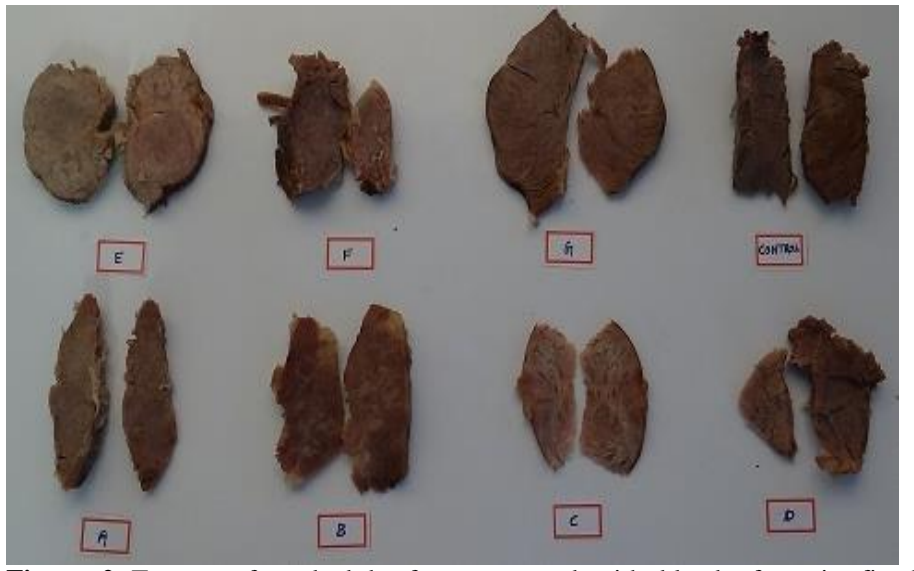

Figure 2 Texture of cooked beef meat treated with blend of semi-refined carrageenan (MK-250) and different phosphates

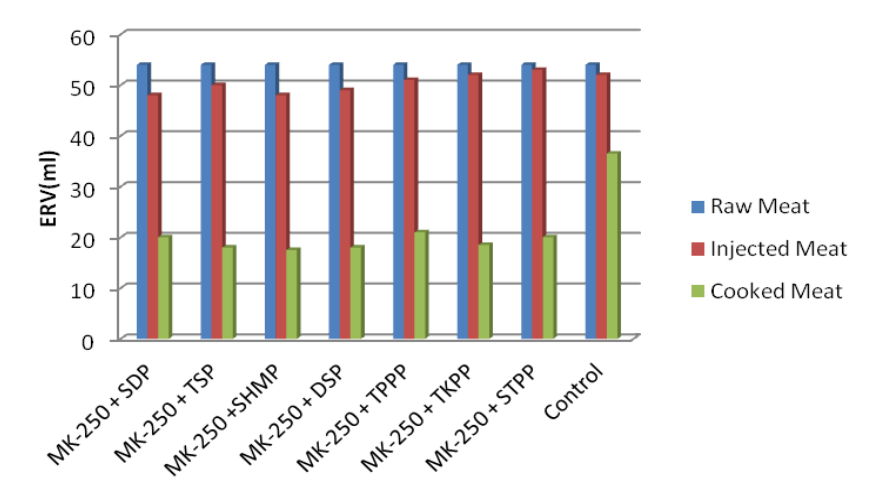

Figure 3 Effect of semi-refined carrageenan (MK- 250) and different phosphates on Extract Release Volume of beef meat

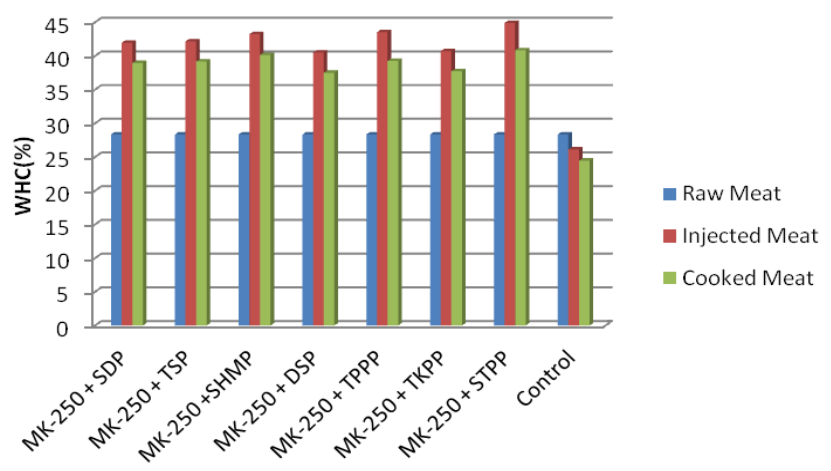

Figure 4 Effect of semi-refined carrageenan (MK- 250) and different phosphates on Water Holding Capacity of beef meat

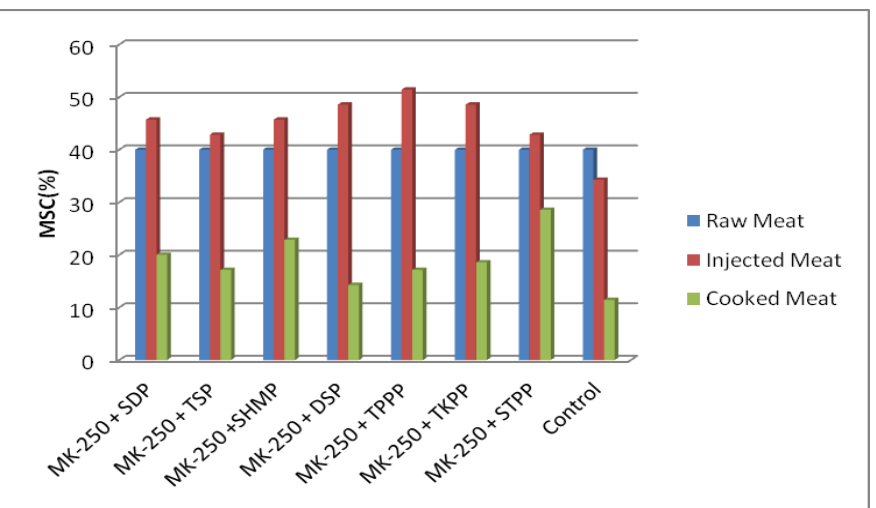

Figure 5 Effect of semi-refined carrageenan (MK- 250) and different phosphates on Meat Swelling Capacity of beef meat

\section{Sensory properties}

Palatability of treated along with control meat samples were evaluated by 10 panellists. Panellists gave feedback that acceptability all treated meat samples were very good as compared to control sample. On the basis of 9 hedonic scales the sensory analysis score card of SRC (MK-250) added with different phosphate salts on beef meat are showed in the Table 4. Brine injected samples had higher values in all sensory attributes like appearance, colour, odour, juiciness, texture, tenderness and flavour than control sample.

Table 4 Appearance and sensory analysis of beef meat injected with blend of SRC (MK- 250) and different phosphates

\begin{tabular}{|c|c|c|c|c|c|c|c|c|}
\hline Blend/Traits & Appearance & Color & Odour & Juiciness & Texture & Tenderness & Flavor & Overall Palatability \\
\hline $\mathrm{MK}-250+\mathrm{SDP}$ & 6 & 6 & 6 & 5 & 8 & 7 & 7 & 6.4 \\
\hline MK-250 + TSP & 6 & 7 & 6 & 6 & 7 & 7 & 7 & 6.5 \\
\hline MK-250 +SHMP & 7 & 8 & 8 & 6 & 8 & 5 & 7 & 7 \\
\hline $\mathrm{MK}-250+\mathrm{DSP}$ & 6 & 6 & 7 & 6 & 7 & 5 & 7 & 6.2 \\
\hline MK-250 + TPPP & 6 & 7 & 7 & 6 & 7 & 6 & 8 & 6.7 \\
\hline MK-250 + TKPP & 6 & 6 & 5 & 6 & 5 & 7 & 7 & 6 \\
\hline MK-250 + STPP & 7 & 8 & 8 & 7 & 8 & 7 & 8 & 7.5 \\
\hline Control & 6 & 6 & 5 & 6 & 5 & 6 & 6 & 5.7 \\
\hline
\end{tabular}

In the aspects of appearance of meat injected with brine made up of STPP and TPPP got maximum scores among other treated samples and control was the least cored product. The brine made with salts such as TSP, SHMP and TPPP accounted very good status in colour, while brine of TKPP treated sample and control were in the last level. Odour and flavour was commonly shared the same level in the score card i.e. there was no such hyper variations among brine made with all the phosphate salts tested. In juiciness, mostly panellist preferred SHMP, TPPP and STPP over the other salts and the control product. These results are in agreement with literature reports that juiciness of meat increased when it was phosphated (Baublits et al., 2005; Miller and Harrison, 1965; McGee et al., 2003) an enhanced flavour in beef and pork (Smith $\boldsymbol{e t}$ al., 1984; McGee $\boldsymbol{e t}$ al., 2003; Scanga et al., 2000). Texture and tenderness were mostly in the friendly zone as STPP scored recorded maximum level of point for both texture and tenderness followed by TSP, SHMP, TPPP, other phosphates and control. In the overall acceptability, panelists given maximum score to meat treated with brine made up of STPP and SRC (KM-250) followed by other brines SHMP, TPPP, TSP, SDP, DSP, TKPP and finally control. Therefore, STPP among all seven salts used for making brine with SRC (MK-250) performed well in terms of weight gain and improvements in texture and sensory when injected into beef meat.

\section{CONCLUSIONS}

Beef injected with blend of semi-refined carrageenan (MK-250) and phosphates like SDP, TSP, SHMP, DSP, TPPP, TKPP and STPP yielded higher weight gain with improved sensory properties like tenderness, juiciness, color and flavour as compared to control sample. Among seven phosphates tested, STPP performed well in terms of weight gain i.e. $24 \%$, improved quality parameters and less cooking loss as compared to other phosphate salts, therefore, it can be concluded from the present investigation that there is potential use of blend made with STPP and semi-refined carrageenan (MK-250) in the beef processing industry.

Acknowledgment: Authors are very grateful to Mr. Abhiram Seth, MD, Mr. Arun Patnaik, CEO and Mr. Tanmaye Seth of AquAgri Processing Private Limited for their constant encouragements, guidance and facilities created for the present investigation.

\section{REFERENCES}

Alvarado, C. and McKee, S. (2007). Marination to improve functional properties and safety of poultry meat. Journal of Applied Poultry Research, 16, 113-120. http://dx.doi:10.1093/japr/16.1.113 
Anjaneyulu, A. S. R., Sharma, N. and Kondaiah, N. (1989). Evaluation of salt, polyphosphates and their blends at different levels on physicochemical properties of buffalo meat and patties. Meat Science, 25, 293-306. http://dx.doi.org/10.1016/0309-1740(89)90047-8

Anjaneyulu, A. S. R., Sharma, N. and Kondaiah, N. (1990). Specific effect of phosphate on the functional properties and yield of buffalo meat patties. Food Chemistry, 36,149-154. http://dx.doi: 10.1016/0308-8146(90)90098-O

AOAC.(1990). Official Methods of Analysis. $15^{\text {th }}$ ed. Association of Official Analytical Chemists, Arlington.

Ayadi, M., Kechaou, A., Makni, I. and Attia, H. (2009). Influence of carrageenan addition on turkey meat sausages properties. Journal of Food Engineering, 93: 278-283. http://dx.doi: 10.1016/j.jfoodeng.2009.01.033

Baublits, R. T., Pohlman, F.W., Brown, A. H. and Johnson, Z. B. (2005). Effect of Enhancement with Varying Phosphate Types and Concentrations at Two Pump Rates on Beef Biceps Femoris Quality and Sensory Characteristics, Arkansas Animal Science Department Report.

Baumert, J. L. and Mandigo, R. W. (2005). The Effects of Phosphate Type and Potassium Lactate Level on Quality Characteristics of Enhanced Beef Steaks, Nebraska Beef Cattle Reports, animal study report.

Bess, K. N. (2011). Effects of various salt purity levels on lipid oxidation and sensory characteristics of ground turkey and pork, Ph.D. Thesis Dissertation, University of Illinois at Urbana, Illinois, Urbana.

Bixler, H. J. and Porse, H. (2011). A decade of change in the seaweed hydrocolloids industry. Journal of Applied Phycology, 23, 321-335. http://dx.doi:10.1007/ s10811-010-9529-3

Candogan, K. and Kolsarici, N. (2003a). The effects of carrageenan and pectin on some quality characteristics of low-fat beef frankfurters. Meat Science, 64,199206. http://dx.doi: 10.1016/S0309-1740(02)00181-X

Candogan, K. and Kolsarici, N. (2003b). Storage stability of low-fat beef frankfurters formulated with carrageenan or carrageenan with pectin. Meat Science, 64, 207- 214

DeFreitas, Z., Sebranek, J., Olson, D. and Carr, J. (1997). Carrageenan effects on thermal stability of meat proteins. Journal of Food Science, 62, 544-547. http://dx.doi: 10.1111/j.1365-2621.1997.tb04426.x

Drummond, L.S. and Da-Wen Sun. (2006). Feasibility of water immersion cooking of beef joints: Effect on product quality and yield. Journal of Food Enineering, 77, 289-294. http://dx.doi:10.1016/j.jfoodeng.2005.06.032

Feiner, G. (2006). Meat products handbook - Practical science and technology. Wood head Publishing Limited, Cambridge, England.

Fernández-López, J., Sayas-Barberá, E., Pérez-Alvarez, A. J. and Aranda-Catalá, V. (2004). Effect of sodium chloride, sodium tripolyphosphate and $\mathrm{pH}$ on colour properties of pork meat. Color Research Application, 29, 67-74 http://dx.doi: 10.1002/col.10215

Garcia, C.E.R., Fabio, Y., Elza, Y.Y., Sandra, H.P. and Massami, S. (2013) Effect of Carrageenan Addition on the Yield and Functional Properties of Charqui (Jerked Beef). Brazilian Archive Biological Technology, 56, 311-318. http://dx.doi.org/10.1590/S1516-89132013000200017

Giese, J. (1992). Developing low-fat meat products. Food Technology, 46, 100 108.

Hsu, S. Y. and Chung, H. Y. (2001). Effects of kappa-carrageenan, salt, phosphates and fat on qualities of low fat emulsified meatballs. Journal of Food Enineering, 47, 115-121.

Jay, M. (1964). Release of aqueous extracts by beef homogenates and factors, Food Technology, 18, 129-132.

Kauffman, R. G., Einnkelemboom, G., Vander, P. G. and Zaar, M. A. (1986) Comparison of methods to estimate water-holding capacity in post-rigor porcine muscle. Meat Science, 18, 307-322.

Knipe, L. (2003). Phosphates as meat emulsion stabilizers, In: C. Benjamin (Ed.) Encyclopaedia of Food Sciences and Nutrition, Academic Press, Oxford. 20772080.

Lee, N., V. Sharma., Singh, R. and Mohan, A. (2014). Effects of injection enhancement carrageenan, sea-salt, and potassium lactate on beef longissimus lumborum muscle sensorial characteristics and color stability. Journal of Food Process Technology, 5, 400 .

Leora, A., James. and Jay, M. (2006). Relationship between meat swelling, viscosity, extract release volume, and water holding capacity in evaluating beef microbial quality. Journal of Food Science, 34(6), 532-535. http://dx.doi: 10.1111/j.1365-2621.1969.tb12080.x

McGee, M. R., Henry, K. L., Brooks, J. C., Ray, F. K. and Morgan, J. B. (2003) Injection of sodium chloride, sodium tripolyphosphate, and sodium lactate improves Warner-Bratzler shear and sensory characteristics of pre-cooked inside round roasts. Meat Science,64, 273-277. http://dx.doi: 10.1016/S03091740(02)00189-4

Miller, E. M. and Harrison, D. L. (1965). Effect of marination in sodium hexametaphosphate solution on the palatability of loin steaks. Food Technology, 19, 94-97. http://dx.doi: 10.1016/S0309-1740(96)00093-9

Molins, R. A .(1991). Phosphates in Food. CRC Press, Inc., Boca Raton.

Moiseev, I. V. and Cornforth, D. P. (1997). Sodium hydroxide and sodium tripolyphosphate effects on bind strength and sensory characteristics of restructured beef rolls. Meat Science, 45, 53-60.
Offer, G. and Trinick, J. (1983). On the mechanism of water holding in meat. The swelling and shrinking of myofibrils. Meat Science, 8, 245-281. http://dx.doi: 10.1016/j.meatsci.2005.04.022

Pietrasik, Z. and Duda, Z. (2000). Effect of fat content and soy protein/ carrageenan mix on the quality characteristics of comminuted, scalded sausages. Meat Science, 56 (2), 181-188.

Pietrasik, Z. and Li-Chan, E. C. Y. (2002). Binding and textural properties of beef gels as affected by protein, j-carrageenan and microbial transglutaminase addition. Food Research International, 35(1), 91-98.

Pietrasik, Z. (2003). Binding and textural properties of beef gels processed with jcarrageenan, egg albumin and microbial transglutaminase. Meat Science, 63(3), 317-324.

Sheard, P. R., Nute, G. R., Richardson, R. I, Perry, A. and Taylor, A. A. (1999) Injection of water and polyphosphate into pork to improve juiciness and tenderness after cooking. Meat Science, 51, 371-376. http://dx.doi:10.1016/S0309-1740 (98)00136-3

Scanga, J. A., Delmore, R. J., Ames, R. P., Belk, R. L., Tatum.J. D. and Smith, G. C.(2000). Palatability of beef steaks marinated with solutions of calcium chloride, phosphate, and (or) beef-flavoring. Meat Science, 55, 397-401.

Smith, L. A., Simmons, S. L., McKeith, F. K., Bechtel, P. J. and Brady, P. A (1984). Effects of sodium tripolyphosphate on physical and sensory properties of beef and pork roasts. Journal of Food Science, 49, 1636-1641. http://dx.doi: 10.1111/j.1365-2621.1984.tb12869.x

Steel, R., Torrie, J. and Dickey, D. (1996). Principles and Procedures of Statistics. A biometrical Approach, 3rd Ed. Mc Graw Hill Book Co., New York.

Therkelsen, G. H., Whistler, R. L. and BeMiller, J. R. (1993). Industrial gums, polysaccharides and their derivatives, San Diego, CA: Academic Press. 145-150. Torley, P. J. and Trout, G. R. (2000). The effect of ionic strength, polyphosphates type, $\mathrm{pH}$, cooking temperature and pre blending on the functional properties of normal and pale, soft, exudative pork. Meat Science, 55, 451-462.

Trout, G. R. (1998). Techniques for measuring water binding capacity in muscle foods - a review of methodology. Meat Science, 70(3), 138-141.

Verbeken, D., Neirinck, N., Van Der Meeren, P. and Dewettinck, K. (2005) Influence of $\kappa$ carrageenan on the thermal gelation of salt-soluble meat proteins. Meat Science, 70(1),161-6.

Walsh, H., Martins, S. O., O’Neill, E. E., Kerry, J. P., Kenny, T. and Ward, P. (2010). The effects of different cooking regimes on the cook yield and tenderness of non-injected and injection enhanced forequarter beef muscles. Meat Science, 84, 444-448. http://dx.doi: 10.1016/j.meatsci.2009.09.014

Wierbicki, E. and Howker, J. J. (1976). Effect of salt, phosphates and other curing ingredients on shrinkage of lean pork meat and the quality of smoked processed ham. Journal of Food Safety, 41,1116-1121.

Xiong, Y. L., Noel, D. C. and Moody, W. G. (1999). Textural and sensory properties of low-fat beef sausages with added water and polysaccharides as affected by $\mathrm{pH}$ and salt. Journal of Food Science, 64, 550-554. http://dx.doi: 10.1111/j.1365-2621.1999.tb15083.x

Zayas, J.F. (1997). Functionality of proteins in food. Springer-Verlag, Berlin Heidelberg. 